\title{
A Comparison of the Nitrogen Requirements of the Eastern Pygmy Possum, Cercartetus nanus, on a Pollen and on a Mealworm Diet
}

Ian G. van Tets ${ }^{*}$

Anthony J. Hulbert

Department of Biological Sciences, University of

Wollongong, Wollongong, New South Wales 2522, Australia

Accepted 7/29/98

\section{ABSTRACT}

The eastern pygmy possum, Cercartetus nanus, is known to feed both on flower products and on invertebrates. This study compares its ability to meet its nitrogen requirements on pollen and on insect larvae. Captive C. nanus were fed diets in which nitrogen was provided either by Eucalyptus pollen or by the mealworm Tenebrio molitor. The apparent digestibility of the nitrogen from both sources was high, with a mean value of $76 \%$ for the pollen and $73 \%$ for the mealworms. This was much higher than would have been inferred from the common practice of measuring the percentage of empty pollen grains in fecal samples. The truly digestible maintenance nitrogen requirements of C. nanus on pollen were exceptionally low: $2.6 \mathrm{mg} \mathrm{N}$ $\mathrm{d}^{-1}$ compared with $9.5 \mathrm{mg} \mathrm{N} \mathrm{d} \mathrm{N}^{-1}$ on mealworms. The value for pollen is the lowest yet recorded for any mammal. The difference between the requirements of $C$. nanus on the two diets appeared to be related to the composition of the mealworm and pollen protein. The biological value of the pollen nitrogen was exceptionally high for a plant protein, at $72 \%$, whereas the biological value of the mealworm nitrogen was only $42 \%$. This suggests that the amino acid composition of the pollen corresponded more closely to the requirements of C. nanus than the composition of the mealworm protein did. Pollen is an excellent source of nitrogen for C. nanus, and it should be considered as a potential nitrogen source for other flower-feeding animals.

\footnotetext{
${ }^{\star}$ To whom correspondence should be addressed. Present address: Department of Zoology, University of Cape Town, Rondebosch 7701, South Africa; e-mail: ivantets@botzoo.uct.ac.za.
}

Physiological and Biochemical Zoology 72(2):127-137. 1999. (C) 1999 by The University of Chicago. All rights reserved. 1522-2152/99/7202-9743\$03.00

\section{Introduction}

Many mammal species feed on flowers or flower products. For example, in Britain, the dormouse, Muscardinus avellanarius, feeds on the anthers of hawthorn, Crataegus monogyna, in early spring (Richards et al. 1984) and, in the Kalahari desert, Acacia flowers are eaten in large quantities by larger mammals such as springbok, Antidorcas marsupialis, and giraffe, Giraffa camelopardalis (Sauer 1983; Nagy and Knight 1994). Although in many cases the plants receive no corresponding benefit, a range of mammal species including bats, rodents, marsupials, primates, and insectivores are involved in the pollination of various plant species (Rebelo and Breytenbach 1987; Goldingay et al. 1991; Ferrari and Strier 1992; Fleming and Sosa 1994).

The two flower products on which mammals are most likely to feed are nectar and pollen. Nectar, a sugar solution produced by many flowers to attract pollinators, may be a useful energy source for a small mammal, and pollen may provide a source of protein. The pollen of some mammal-pollinated Banksia species contains over 30\% crude protein (Turner 1984a). The bulk of the protein is found in the cell contents, known as the protoplast, which is encased within a hard cell wall that is extremely resistant to chemical breakdown (Raven et al. 1986). The strength of this cell wall has led to a belief that it is difficult for small mammals to extract nutrients from pollen (Hume 1982). Some dietary studies have identified pollen as a major component of fecal samples but discounted it as a possible source of nutrition because of this perceived difficulty (e.g., Smith 1982).

Despite this, fecal analysis has shown that a wide range of mammal species, mainly marsupials, but also rodents, elephant shrews, and bats, remove the protoplast from most of the pollen grains that pass through their gut (van Tets 1997; van Tets and Whelan 1997). Furthermore, the biological value of eucalyptus pollen to Petaurus breviceps, a 150 g flower-feeding marsupial, was found to be high (66\%; Smith and Green 1987), and its truly digestible maintenance nitrogen requirements on pollen were exceptionally low (73 mg N kg ${ }^{-0.75} \mathrm{~d}^{-1}$; Smith and Green 1987). The maintenance nitrogen requirements of a flowerfeeding bat, Syconycteris australis, also fed eucalyptus pollen were also relatively low for a eutherian mammal $(273 \mathrm{mg} \mathrm{N}$ $\mathrm{kg}^{-0.75} \mathrm{~d}^{-1}$; Law 1992a). The normal values for maintenance nitrogen requirements are $582 \pm 235 \mathrm{mg} \mathrm{N} \mathrm{kg}^{-0.75} \mathrm{~d}^{-1}$ for eutherian mammals and $356 \pm 136 \mathrm{mg} \mathrm{N} \mathrm{kg}^{-0.75} \mathrm{~d}^{-1}$ for marsupials (Robbins 1993).

The eastern pygmy possum, Cercartetus nanus, a small ( 25 
g) arboreal marsupial, ingests large quantities of pollen at certain times of the year, and on average two-thirds of these grains are empty (van Tets and Whelan 1997). While it is likely that pollen is an important element in the diet of $C$. nanus at these times, this is not necessarily the case. Pollen may be nutritionally insignificant, and its presence in the feces merely an indication of the importance of nectar. Any small mammal that fed extensively on nectar would ingest and excrete large quantities of pollen. The amino acids contained in the pollen may have been excreted in the feces or, if absorbed, may have been metabolized and their nitrogen lost as urea in the urine if the proportions of the different amino acids did not match the animal's needs.

In addition to pollen, insects are also a major component of the feces of C. nanus (van Tets and Whelan 1997) and, in some areas, seeds may make up a large proportion of the diet (Arnould 1986). Insects and seeds may be more important sources of protein for $C$. nanus than pollen. The ability of $C$. nanus (or any member of its family, the Burramyidae) to meet its nitrogen requirements has not been measured on any diet. In the absence of these data, the value of pollen protein relative to that of other protein sources in the diet of $C$. nanus remains unclear. To compare the nitrogen requirements of C. nanus on a pollen diet with its requirements on an invertebrate protein source, six feeding trials were conducted using captive $C$. nanus. In the first three trials, pollen was the sole protein source, and in the latter three, the mealworm, Tenebrio molitor (O. Coleoptera, F. Tenebrionidae). Mealworms were chosen for the comparison as they were readily available and because fragments from insects (including beetle larvae) were common in fecal samples from $C$. nanus at the same times of the year as pollen (van Tets and Whelan 1997).

The trials were designed to answer a series of questions. First, what was the apparent digestibility of the pollen nitrogen, and what proportion of the dietary nitrogen intake was excreted in the feces? To date, studies of pollen in the diet of mammals have measured the percentage of empty protoplasts in the feces of various mammals and used that as a basis of comparison of the ability of mammals to digest pollen nitrogen (Turner 1984a, 1984b; Richardson et al. 1986; Goldingay et al. 1987; Huang et al. 1987; Law 1992b; Woodside and Pyke 1995). It is relatively easy to measure full and empty protoplasts, but as the amount of nitrogen leached from full protoplasts and the amount bound to empty ones is not known, such a measurement cannot be a precise indication of nitrogen digestibility. Second, how much pollen or mealworm nitrogen was required for C. nanus to maintain nitrogen balance? This question can be answered in two ways. The dietary maintenance nitrogen requirement measures the total amount of nitrogen required to maintain nitrogen balance on a particular diet, while the truly digestible maintenance nitrogen requirement measures only the amount of truly digestible nitrogen that is required at balance. The truly digestible nitrogen intake is the fraction of the total nitrogen intake that crosses the gut wall and is not lost as feces. The two values are often very similar, but if there is a large quantity of nitrogen bound in material that the animal cannot digest, the truly digestible maintenance nitrogen requirement may be substantially lower than dietary requirement.

Third, what were the biological values of the two protein sources to $C$. nanus? While the amount of digestible nitrogen may be high, if the composition of the nitrogenous compounds does not match the animal's needs, a large proportion may be excreted in the urine. The biological value of a protein source provides a measure of the percentage of the truly digestible nitrogen intake that is retained by the mammal in body tissue when it is in nitrogen balance. This measurement is a reflection of the quality of the protein source for the particular species. Protein sources with amino acid compositions that closely match the requirements of the animal will have high biological values and are, therefore, regarded as high-quality sources. Lowquality protein sources are those that are deficient in essential amino acids or whose amino acid composition does not match the animal's requirements. As a large proportion of the absorbed nitrogen from such sources will be excreted, they have low biological values.

\section{Material and Methods}

Cercartetus nanus were trapped in the Barren Ground Nature Reserve, near Wollongong in southeastern Australia. Between feeding trials, the animals were kept indoors in two $1-\mathrm{m}^{3}$ holding cages and fed a mixture of muesli and dried fruit. For feeding trials, eight male $C$. nanus were taken from their holding cages at 1200 hours. They were weighed and placed in individual metabolism cages. The room in which the metabolism cages were kept was maintained at a temperature between $17^{\circ} \mathrm{C}$ and $21^{\circ} \mathrm{C}$. The food and water dishes in the metabolism cages could contain a maximum of $4 \mathrm{~mL}$ each of food and water. At the start of each trial, $4 \mathrm{~mL}$ of the food, an agar-based gel, was poured into the feeding dishes as a liquid at $60^{\circ} \mathrm{C}$. It was then allowed to cool and set before the animals were placed in the cages. Six feeding trials were conducted using different proportions of either pollen or mealworms in an agar/sugar solution. The basic agar solution was made from $400 \mathrm{~mL}$ of water, $5 \mathrm{~g}$ of agar (Oxoid-Technical no. 3), $26.7 \mathrm{~g}$ each of sucrose, fructose, and glucose, and $0.075 \mathrm{~g}$ of a multivitamin supplement. The mass of pollen or mealworms added to the agar solution in the six trials and the nitrogen content of each trial food are given in Table 1 . The pollen was obtained commercially and was composed of 95\% eucalyptus pollen, 2\% Banksia pollen, and $3 \%$ other pollen species. This mixture was similar to the combinations used in previous experiments on pollen-feeding mammals (Smith and Green 1987; Law 1992a). The mealworms were also obtained commercially and were chopped into 1-2-mm fragments before being added to the solution. The crude protein content of the pollen mixture and its total amino 
Table 1: Mass of protein source added to $40 \mathrm{~mL}$ of agar solution for each trial and the nitrogen content of each trial food

\begin{tabular}{|c|c|c|c|c|c|c|}
\hline \multirow[b]{2}{*}{ Trial } & \multicolumn{3}{|l|}{ Pollen } & \multicolumn{3}{|c|}{ Mealworm } \\
\hline & Low $\mathrm{N}$ & Medium N & High $N$ & Low $\mathrm{N}$ & Medium N & High N \\
\hline 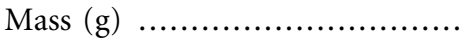 & 1 & 3 & 5 & 1 & 3 & 5 \\
\hline $\begin{array}{l}\text { Dietary nitrogen content } \\
\qquad\left(\mathrm{mg} \mathrm{N} \mathrm{g}{ }^{-1} \text { dry weight }\right) \ldots \ldots \ldots\end{array}$ & 11.8 & 29.5 & 42.3 & 11.4 & 32.2 & 50.7 \\
\hline
\end{tabular}

Note. The solution contained $0.08 \mathrm{mg} \mathrm{N} \mathrm{g}^{-1}$ dry weight when no protein source was added.

acid composition were determined for us by the Centre for Molecular Structure and Function at the Australian National University, using a high-performance liquid chromatography (HPLC) amino acid analyzer. The amino acid compositions of the pollen mixture and of mealworm haemolymph (Tomlin et al. 1993) are shown in Table 2. The amino acid composition of Banksia ericifolia pollen has been included for comparison (Stace 1987; P. Stace, unpublished data), as empty B. ericifolia pollen grains have been found in large quantities in $C$. nanus feces (van Tets and Whelan 1997). The eucalyptus pollen mixture contained $18.6 \%$ (wt/wt) protein, and the mealworms are reported to contain $20.8 \%$ (wt/wt) protein (Frye 1993). The percentage crude protein value for the eucalyptus pollen mixture was an underestimate as tryptophan was not included. Tryptophan is destroyed during hydrolysis of extracted protein (Dadd 1977), and the HPLC analyzer used was unable to measure it. However, the percentage crude protein of the mixture was unlikely to be much more than $20 \%$ (wt/wt) as tryptophan comprises less than $3 \%\left(\mathrm{~mol} \mathrm{~mol} \mathrm{~m}^{-1}\right.$ amino acid) of most food proteins (Moir 1994). Kjeldahl analysis of both diets revealed more nitrogen than could be explained by this percentage of protein. If the protein in the mealworms and the pollen contained 16\% (wt/wt) nitrogen (Brody 1974), then the mealworms contained $3.3 \%$ protein nitrogen and $7.5 \%$ nonprotein nitrogen, and the pollen mixture contained $3.0 \%$ protein nitrogen and $9.0 \%$ nonprotein nitrogen. It seems likely that most of the nonprotein nitrogen came from chitin in the case of the mealworms and from nucleic acids in the case of the pollen.

Fresh food and water were added daily while the animals were asleep. The food solution was always $60^{\circ} \mathrm{C}$ when placed in the cages but cooled to room temperature and set before consumption. The animals were allowed an acclimation period of four nights. The trial proper lasted for five nights. During the trials, animals were weighed daily at 1200 hours. Animals that lost more than $10 \%$ of their body weight during a trial were returned to the holding cages and excluded from that experiment.

The lower portion of the metabolism cages was funnel shaped and the cages drained into specimen jars containing $20 \mathrm{~mL}$ of $2.5 \%(\mathrm{w} / \mathrm{v})$ hydrochloric acid $(\mathrm{HCl})$ to prevent the loss of urinary nitrogen as ammonia. An ovoid glass ball, which was placed on top of the specimen jar, allowed urine to run into the jar but deflected the feces into a petri dish. Four small glass legs, attached to the lower portion of the ball, enabled it to sit on the specimen jar without completely sealing it. Following the trials, the nitrogen content of the diets, the feces collected, the urine collected, and the basic agar solution were all determined using Kjeldahl analysis. All samples were dried to constant mass in an oven at $60^{\circ} \mathrm{C}$ and weighed before analysis. From the results of the Kjeldahl analysis, the dietary nitrogen intake and the amount of nitrogen in the feces and urine of each animal were determined. These values were used to calculate a series of measurements that were related to the ability of $C$. nanus to use pollen and mealworm nitrogen. These measurements were the apparent digestibility of nitrogen, the dietary and the truly digestible maintenance nitrogen requirements of C. nanus, and the biological value of the nitrogen sources. The apparent digestibility of nitrogen was calculated for each animal on each trial as follows: $A D N=(d N I-F N) / d N I$, where $d N I$ is the dietary nitrogen intake, $A D N$ is the apparent digestibility of nitrogen, and FN represents fecal nitrogen. From these values, the mean values of the apparent digestibility of pollen and mealworm nitrogen to C. nanus were calculated. A $t$-test (Zar 1996) was used to compare the apparent digestibility of nitrogen for each food source.

The maintenance nitrogen requirements of $C$. nanus were measured by the linear regression of nitrogen balance (total nitrogen intake minus total nitrogen excreted) against nitrogen intake (either dietary or truly digestible nitrogen intake as required). The maintenance nitrogen requirement is the value for nitrogen intake when nitrogen balance equals zero. A variant of Student's $t$-test (formulae 17.25 and 17.26 in Zar 1996) was used to compare the maintenance nitrogen requirements for C. nanus on the two food sources.

The truly digestible nitrogen intake was calculated by subtracting the amount of nitrogen lost in the feces, corrected for the amount of metabolic fecal nitrogen, from the dietary nitrogen intake. That is, $t d N I=d N I-(F N-M F N)$, where $M F N$ is the metabolic fecal nitrogen and $t d N I$ is the truly digestible nitrogen intake. The level of metabolic fecal nitrogen was determined by the linear regression of fecal nitrogen per gram dry matter intake against dietary nitrogen content (expressed in $\mathrm{mg} \mathrm{N}$ dry weight ${ }^{-1}$ ) and solving for a dietary nitrogen content of zero (Bosshardt and Barnes 1946).

The biological value of the nitrogen sources was calculated by regressing urinary nitrogen against truly digestible nitrogen 
Table 2: Percentage of each amino acid in the total amino acid composition of the eucalyptus pollen mixture, Banksia ericifolia pollen, and the mealworm, Tenebrio molitor

\begin{tabular}{|c|c|c|c|}
\hline Amino Acid & $\begin{array}{l}\text { Eucalyptus Pollen } \\
\text { Mixture }\end{array}$ & $\begin{array}{l}\text { Banksia ericifolia }{ }^{\text {a }} \\
\text { Pollen }\end{array}$ & $\begin{array}{l}\text { Tenebrio molitor } \\
\text { Haemolymph }\end{array}$ \\
\hline Methionine .......... & 1.7 & 1.6 & .1 \\
\hline Lysine ................ & 5.5 & 7.6 & 4.4 \\
\hline Arginine $\ldots . . . . . . . .$. & 5.9 & 9.5 & 2.3 \\
\hline Histidine ............. & 1.9 & 3.1 & 5.9 \\
\hline Iso-leucine ........... & 3.3 & 3.5 & 2.4 \\
\hline Leucine ............... & 6.6 & 7.2 & 1.6 \\
\hline Phenylalanine ....... & 3.0 & 4.3 & 1.3 \\
\hline Threonine .......... & 4.2 & 4.5 & .4 \\
\hline Tryptophan .......... & N.M. & 2.8 & .6 \\
\hline Valine.............. & 4.7 & 4.1 & 5.7 \\
\hline Subtotal .............. & 36.8 & 46.3 & 24.6 \\
\hline Alanine ............... & 8.6 & 5.0 & 2.8 \\
\hline Aspartic acid ${ }^{c} \ldots . .$. & 11.6 & 9.9 & $0(3.0)$ \\
\hline Cysteine .............. & 4.5 & 1.1 & N.M. \\
\hline Glutamic acid ${ }^{c} \ldots . .$. & 10.9 & 12.1 & $.1(17.3)$ \\
\hline Glycine .............. & 9.8 & 4.3 & 1.4 \\
\hline Proline $\ldots . . . . . . . . .$. & 10.6 & 8.3 & 43.9 \\
\hline Serine............. & 6.3 & 4.9 & 4.7 \\
\hline Tyrosine .............. & 1.0 & 6.6 & 2.3 \\
\hline
\end{tabular}

Note. The 10 major essential amino acids are listed first, followed by the other amino acids in alphabetical order. The amino acid analyzer used for the eucalyptus mixture was unable to measure tryptophan (Dadd 1977; Stace 1987). Therefore, tryptophan was not included in the calculation of the total moles of amino acid in the eucalyptus pollen mixture. N.M. indicates not measured.

a Stace 1987; P. Stace, unpublished data.

b Tomlin et al. 1993 .

c The pollen analyses measured aspartic acid and glutamic acid. Tomlin et al. (1993) reported separate values for aspartate (asparagine) and glutamate (glutamine).

intake. The biological value was equal to one minus the slope of this regression (Smith and Green 1987). The level of endogenous urinary nitrogen was also determined by the same regression as it was taken to be the amount of urinary nitrogen when the truly digestible nitrogen intake was zero (Robbins 1993). The biological values calculated from the slope of the regression were compared using a $t$-test variant (formulae 17.1 and 17.2 in Zar 1996).

Ten milligrams of the feces produced by each $C$. nanus during the medium- and high-pollen trials were spread on a microscope slide and the percentage of visibly empty eucalyptus and Banksia pollen grains was recorded. Feces from the low-pollen trial were not used, as the entire sample was used in the Kjeldahl analysis. The proportion of empty Banksia grains in the feces was compared with the proportion recorded for wild C. nanus (van Tets and Whelan 1997) using a $t$-test (Zar 1996).

\section{Results}

All the Cercartetus nanus lost weight on both the pollen and the mealworm diets with the lowest concentration of nitrogen.
The mean percentage weight loss was $1.2 \%$ and $1.6 \%$, respectively. In all other trials, the animals gained weight. Mean percentage weight gains were low, ranging from $0.2 \%$ to $0.7 \%$. None of the animals were observed to enter torpor during the feeding trials.

Before ingestion, the pollen in the food was almost entirely intact. The mean proportion of empty eucalyptus grains in the agar solutions used in the pollen trials was $0.7 \% \quad(n=3$, $\mathrm{SE}=0.3$ ), and the mean percentage of empty Banksia grains was $0.3 \%(n=3, \mathrm{SE}=0.3)$. The eucalyptus pollen found in the feces of the $C$. nanus used in the feeding trials contained a mean percentage of $45 \%$ empty grains $(n=12, \mathrm{SE}=1.5)$, while the Banksia pollen found in the feces contained a significantly higher mean percentage of empty grains $(61 \% ; n=$ $12, \mathrm{SE}=1.8, P<0.05)$. This was not significantly different $(P>0.05)$ from the mean percentage of empty Banksia pollen grains in the feces of free-living C. nanus (65\%; van Tets and Whelan 1997). The mean apparent digestibility of pollen nitrogen to C. nanus was $76 \%(\mathrm{SE}=1.8)$. The value for mealworm nitrogen was slightly lower, $73 \%(\mathrm{SE}=2.5)$, but the 
difference was not significant ( $t$-test, $P>0.05$; Zar 1996). This suggests that a large proportion of both the protein and the nonprotein nitrogen contained in the two nitrogen sources was absorbed by $C$. nanus. This would have included a large proportion of the nitrogen contained in the mealworm chitin. There was also no significant difference between the levels of either metabolic fecal nitrogen (Table 3) or endogenous urinary nitrogen (Table 3 ) produced by $C$. nanus on the two diets ( $P>0.05$ in both cases). However, the maintenance nitrogen requirements of $C$. nanus (both dietary and truly digestible) were significantly lower on the pollen diet than they were on the mealworm diet $(P>0.05$, Table 3$)$. The truly digestible maintenance nitrogen requirements (truly digestible nitrogen intake when nitrogen balance equalled zero) for $C$. nanus were $2.6 \mathrm{mg} \mathrm{N} \mathrm{d}^{-1}(\mathrm{SE}=0.5)$ when pollen was the sole protein source and $9.5 \mathrm{mg} \mathrm{N} \mathrm{d}^{-1}(\mathrm{SE}=1.1)$ when mealworms were. The relationships between nitrogen balance and truly digestible nitrogen intake for $C$. nanus on the two diets are shown in Figure 1.

The biological value of the pollen diet was significantly higher $(72 \%, \mathrm{SE}=2)$ than the value of the mealworm diet $(42 \%$, $\mathrm{SE}=3$ ). The relationships between urinary nitrogen and truly digestible nitrogen intake from which the biological values were calculated (biological value $=1-$ the slope of the regression) are shown in Figure 2.

\section{Discussion}

Cercartetus nanus was capable of maintaining nitrogen balance on the pollen diet and both its dietary maintenance nitrogen requirements and its truly digestible maintenance nitrogen requirements were exceptionally low (Table 3). They were lower than any recorded values for mammals and even slightly lower than those of hummingbirds $\left(4.5 \mathrm{mg} \mathrm{N} \mathrm{d}^{-1}\right.$; Brice and Grau 1991). All of the animals in all three pollen trials were in positive nitrogen balance (Fig. 1) and so were absorbing nitrogen in their tissues that they could use for growth or tissue repair. As the proportion of empty Banksia protoplasts in the feces of the experimental animals did not differ significantly from the proportion observed in the feces of free-living C. nanus (van Tets and Whelan 1997), these results should accurately reflect the situation in the field. Cercartetus nanus was also capable of maintaining nitrogen balance on mealworms, albeit with a higher maintenance nitrogen requirement (Table 3 ), and the apparent digestibility of nitrogen from both food sources did not differ significantly. The main reason for the difference between the maintenance nitrogen requirement values of $C$. nanus on the two food sources was the difference in the quality of the two nitrogen sources. The biological value of the pollen to C. nanus was significantly higher than that of the mealworms.

\section{Apparent Digestibility of Nitrogen}

The apparent digestibility of nitrogen from both diets was high $-76 \%$ for pollen and $73 \%$ for mealworms (Table 3 ). The value for pollen was much higher than the percentage of empty eucalyptus pollen grains in the feces $(45 \%)$. Therefore, field studies that use measurements of empty pollen grains in feces to estimate the digestibility of pollen are likely to underestimate considerably the ability of flower-feeding animals to extract nitrogen from pollen.

The high apparent digestibility of the mealworm nitrogen is also of interest as it indicates that $C$. nanus is able to extract nitrogen from chitin. Chitin was the major source of nonprotein nitrogen in the mealworms and, as only one-third of the nitrogen in the mealworms was contained in protein, C. nanus must have removed the nitrogen from some of the chitin it ingested to achieve a digestibility value as high as $73 \%$. The most likely explanation of this result is that either $C$. nanus or its gut flora are capable of producing chitinase enzymes. The production of such enzymes would certainly be useful to a small mammal that feeds extensively on insects.

\section{Maintenance Nitrogen Requirements}

Cercartetus nanus required less nitrogen for maintenance on the pollen diet than it did on the mealworm diet. The difference between the dietary maintenance nitrogen requirement values for $C$. nanus on the two diets was just over $7.6 \mathrm{mg} \mathrm{N} \mathrm{d}^{-1}$ (Table 3). This difference was reduced slightly to $6.9 \mathrm{mg} \mathrm{N} \mathrm{d}^{-1}$ (Table

Table 3: The nitrogen requirements of C. nanus on diets containing either pollen or mealworms

\begin{tabular}{|c|c|c|}
\hline Protein Source & Pollen Diet & Mealworm Diet \\
\hline Body mass $(g)$......................... & $25.4 \pm 1.0$ & $30.9 \pm 1.3$ \\
\hline Apparent digestibility of nitrogen $(\%)$.................... & $76 \pm 2$ & $73 \pm 3$ \\
\hline Dietary maintenance nitrogen requirement $\left(\mathrm{mg} \mathrm{N} \mathrm{d}^{-1}\right) \ldots \ldots \ldots \ldots \ldots$ & $3.2 \pm .7$ & $10.8^{\star} \pm 1.3$ \\
\hline 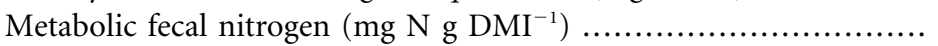 & $.5 \pm 12$ & $1.83 \pm 14$ \\
\hline Truly digestible maintenance nitrogen requirement $\left(\mathrm{mg} \mathrm{N} \mathrm{d}^{-1}\right) \ldots \ldots$ & $2.6 \pm .5$ & $9.5^{\star} \pm 1.1$ \\
\hline 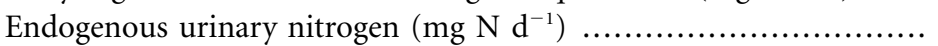 & $1.4 \pm .5$ & $2.6 \pm 1.2$ \\
\hline Biological value $(\%)$................................................... & $72^{*} \pm 2$ & $42 \pm 3$ \\
\hline
\end{tabular}

Note. Values shown are mean values \pm SE.

${ }^{*}$ Value is significantly greater than the corresponding value for the other $\operatorname{diet}(P<0.05)$. 


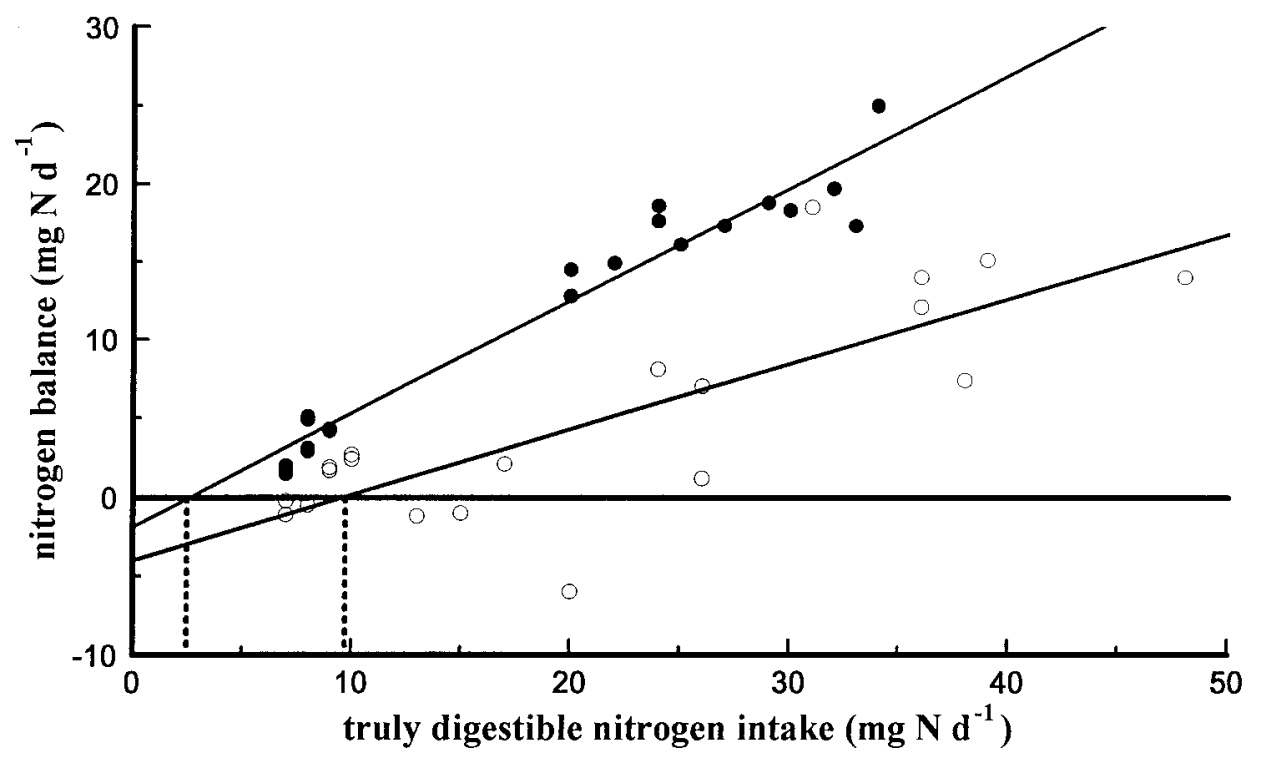

Figure 1. The relationship between nitrogen balance $(N B)$ and the truly digestible nitrogen intake (tdNI) for Cercartetus nanus on the pollen and mealworm diets. Filled circles, C. nanus fed pollen; open circles, C. nanus fed mealworms. For pollen, $N B=0.72 \times t d N I-1.86\left(r^{2}=\right.$ $0.95)$, and for mealworms, $N B=0.42 \times t d N I-3.98\left(r^{2}=0.63\right)$. The truly digestible maintenance nitrogen requirements (truly digestible nitrogen intake when nitrogen balance equals zero) of $C$. nanus on the diets are indicated by the dotted lines perpendicular to the $x$-axis.

3) when the truly digestible maintenance nitrogen requirement was compared. The reduction in the difference between the results for the digestible maintenance nitrogen requirement values was probably due to the excretion of undigested chitin in the feces. This would have decreased the truly digestible nitrogen intake and hence the truly digestible maintenance nitrogen requirement for the mealworm diet. The difference in the maintenance nitrogen requirements of $C$. nanus for the two diets was clearly related to the difference in the biological value of the diets to $C$. nanus. The biological value of the pollen diet to $C$. nanus was much higher than that of the mealworm diet: $72 \%$ as opposed to $43 \%$ (Table 3 ). Therefore, C. nanus was losing a much higher percentage of the truly digestible nitrogen intake in its urine on the mealworm diet than it was when feeding on pollen. This was highlighted by the higher levels of urinary nitrogen excreted during the mealworm trials compared with the pollen trials (Fig. 2). The biological values of the two diets to $C$. nanus are compared with the values of a variety of diets to Rattus norvegicus and with the value of Eucalyptus pollen to Petaurus breviceps in Table 4. The biological value of pollen to the two marsupials was comparable with the value of good quality animal protein to $R$. norvegicus.

As $C$. nanus retained such a high percentage of the pollen nitrogen, it is reasonable to assume that the composition of the amino acids in the pollen mixture matched the amino acid requirements of $C$. nanus more closely than the amino acid composition of the mealworms did. If the amino acid composition had not matched the requirements of $C$. nanus, a large proportion of the nitrogen from the pollen protein would have been converted into urea and excreted in the urine. The high biological value clearly indicates that this did not happen. The lower biological value of the mealworm diet indicated that its amino acid composition was less suitable. It is not clear whether C. nanus had difficulty assimilating the nonprotein nitrogen that it absorbed, whether the amino acid composition of mealworm protein was less suitable than that of the pollen used, or whether a combination of these two situations was responsible. The amino acid composition of the Eucalyptus pollen mixture is shown in Table 2. It contained at least nine of the 10 major essential amino acids (the percentage of tryptophan was not measured) in proportions that are similar to other plant protein sources such as soybeans, wheat, and oats (Moir 1994). Methionine and lysine, the two amino acids that were most likely to be deficient (H. G. Baker and I. Baker, unpublished data, cited in Martínez del Rio 1994; Moir 1994) were present in quantities that compared favorably with high-quality protein sources. The pollen mixture contained $1.7 \%\left(\mathrm{~mol} \mathrm{~mol}^{-1}\right) \mathrm{me}-$ thionine and 5.5\% lysine (Table 2). In soybeans, wheat, and oats between $1 \%$ and $2 \%$ of the total amino acid composition is composed of methionine (Food and Agriculture Organisation 1970-1972; Moir 1994). Wheat and oats contain less than $4 \%$ lysine (Food and Agriculture Organisation 1970-1972; Moir 1994), and soybeans contain just over 6\% (Food and Agriculture Organisation 1970-1972; Moir 1994). High-quality animal protein sources, like beef, usually contain approximately $2 \%$ methionine and between $5 \%$ and $8 \%$ lysine (Food and Agri- 
culture Organisation 1970-1972; Moir 1994). Banksia ericifolia pollen has a similar amino acid composition to the Eucalyptus pollen mixture (Table 2) and may be an even better source of protein. It has a higher crude protein content (30\%-31\%; Stace 1987 ) and a larger proportion of B. ericifolia pollen was composed of the major essential amino acids-45.2\% compared with $36.8 \%$ (Table 2) -although the value for the Eucalyptus pollen mixture does not include tryptophan. The percentage of lysine was higher in B. ericifolia (7.6\%, Table 2) than in the pollen mixture, and both pollen types contained similar proportions of methionine (Eucalyptus, 1.7\%; B. ericifolia, 1.6\%). This amino acid profile and the observation that a higher percentage of Banksia pollen grains than Eucalyptus pollen grains in the feces of $C$. nanus were empty suggest that the biological value of Banksia pollen to C. nanus is at least as high as that of the eucalyptus mixture and may be higher. For the same reason, the maintenance nitrogen requirements of $C$. nanus on Banksia pollen should be low.

The amino acid composition of mealworms (Table 2) differs markedly from the two pollen sources. Mealworm haemolymph is deficient in methionine (containing only $0.1 \%$ ) and has a lower level of lysine $(4.4 \%)$ than either pollen type, and the percentage of the major essential amino acids in the haemolymph is only $24.6 \%$ (Tomlin et al. 1993). Of the other amino acids, the most notable differences are the low levels of aspartate and asparagine in the mealworm and the very high proportion of the haemolymph composed of proline (43.9\%; Tomlin et al. 1993). These differences, in particular the lower proportions
Table 4: Biological values for Cercartetus nanus, Petaurus breviceps, and Rattus norvegicus on a variety of diets

\begin{tabular}{|c|c|}
\hline Species & $\begin{array}{l}\text { Biological } \\
\text { Value (\%) }\end{array}$ \\
\hline \multicolumn{2}{|l|}{ Rattus norvegicus: } \\
\hline Whole egg $. . . . . \ldots \ldots \ldots . . .$. & $95^{\mathrm{a}}$ \\
\hline Milk ...................... & $85^{\mathrm{a}}$ \\
\hline White fish meal .......... & $77^{\mathrm{a}}$ \\
\hline Soya bean meal ........... & $75^{\mathrm{a}}$ \\
\hline Beef muscle ............... & $69^{\mathrm{b}}$ \\
\hline Wheat $\ldots . . . . . . . . . . . . . .$. & $67^{\mathrm{a}}$ \\
\hline Oats ....................... & $65^{\mathrm{a}}$ \\
\hline Groundnut meal ......... & $58^{\mathrm{a}}$ \\
\hline Maize....$\ldots \ldots \ldots \ldots \ldots \ldots$ & $55^{\mathrm{a}}$ \\
\hline Peanut flour .............. & $46^{\mathrm{b}}$ \\
\hline \multicolumn{2}{|l|}{ Cercartetus nanus: } \\
\hline Pollen ....................... & $72^{\mathrm{c}}$ \\
\hline Mealworms ............... & $43^{\mathrm{c}}$ \\
\hline \multicolumn{2}{|l|}{ Petaurus breviceps: } \\
\hline Pollen ...................... & $66^{\mathrm{d}}$ \\
\hline
\end{tabular}

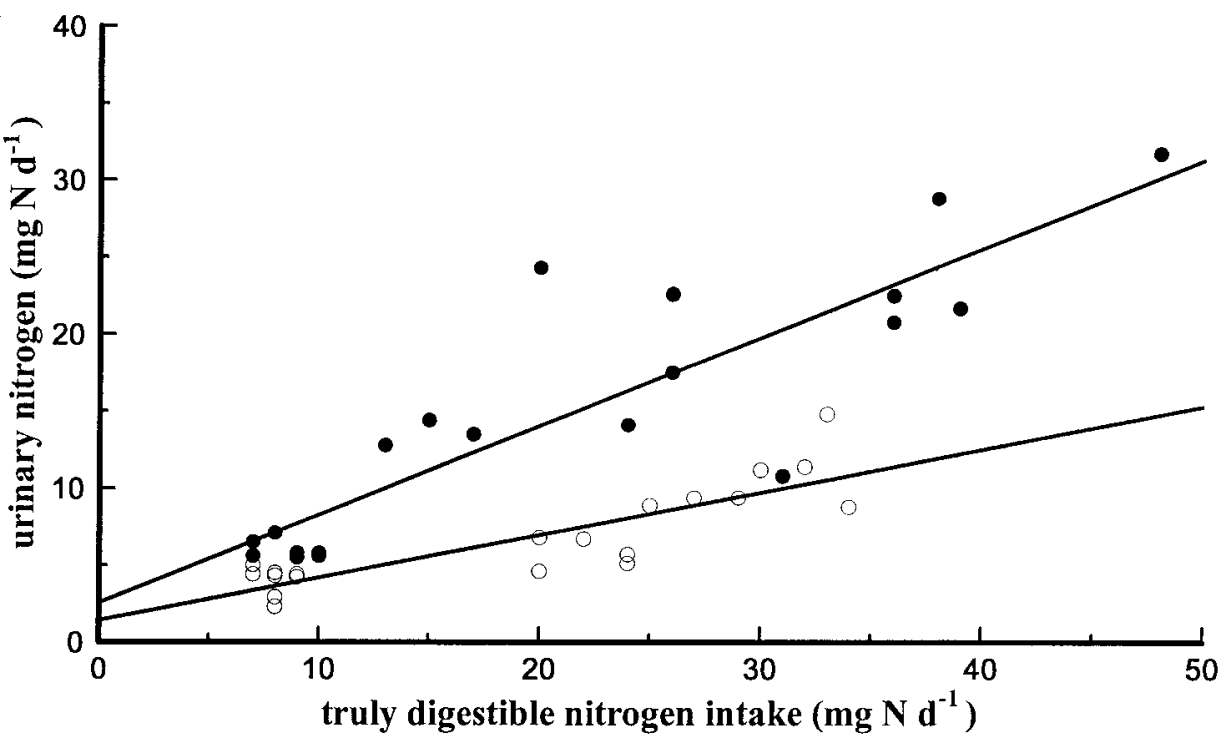

Figure 2. The relationship between urinary nitrogen $(U N)$ and the truly digestible nitrogen intake (tdNI) for Cercartetus nanus on the pollen and mealworm diets. Filled circles, C. nanus fed pollen; open circles, C. nanus fed mealworms. For pollen, $U N=0.28 t d N I+1.4\left(r^{2}=0.73\right)$, and for mealworms, $U N=0.57 t d N I+2.6\left(r^{2}=0.77\right)$. The biological values of the two diets, $(1-$ the slope of the regression $) \times 100 \%$, were $72 \%$ for the pollen diet and $43 \%$ for the mealworms. 
of the major essential amino acids, are the most likely reasons for the low biological value of mealworms for $C$. nanus. However, while the biological value of mealworm nitrogen was low, free-living C. nanus do eat a combination of insects, pollen, and other protein sources. When two or more protein sources are combined, the different sources may compensate for amino acid deficiencies in the others, provided the specific amino acid deficiencies are not common to the protein sources (Brody 1974). Insect protein combined with pollen protein in the diet of $C$. nanus is likely to have a biological value greater than the $43 \%$ measured for the mealworms, and the combination may have a higher value than the $72 \%$ of the eucalyptus pollen mixture on its own.

It is also worth noting that, while the maintenance nitrogen requirements of $C$. nanus were significantly lower on pollen than on mealworms, the maintenance nitrogen requirements of $C$. nanus on both diets were low compared with the recorded values for other marsupials on various diets. Our results do not show that $C$. nanus had difficulty meeting its nitrogen needs on a mealworm diet but, rather, that it met them extremely easily on a diet of pollen. Figure 3 compares the truly digestible maintenance nitrogen requirements and the body mass of a number of marsupials (all from the same order, Diprotodonta). The maintenance nitrogen requirement of $C$. nanus fed mealworms is very close to the predicted value for a 25 -g marsupial, while the value for pollen is much lower.

\section{Pollen and Maintenance Nitrogen Requirements}

Figure 3 also shows the values for two other animals on eucalyptus pollen diets- $P$. breviceps and the blossom bat, Syconycteris australis. Like $C$. nanus, the maintenance nitrogen requirement for $P$. breviceps on pollen is much lower than predicted for a marsupial of its size $\left(18.1 \mathrm{mg} \mathrm{N} \mathrm{d}^{-1}\right.$, mass $=$ $156 \mathrm{~g}$; Smith and Green 1987). In contrast, the truly digestible maintenance nitrogen requirement for $S$. australis relative to its body weight (14.3 $\mathrm{mg} \mathrm{N} \mathrm{d}^{-1}$, mass $=18 \mathrm{~g}$; Law 1992a) was much higher than the values for the two marsupials (Fig. 3) on the same diet. The difference is probably related to the higher basal metabolic rate (BMR) of this species. Eutherians typically have higher BMR values than marsupials (Hume 1982) and $S$. australis is no exception. It has a BMR of $1.93 \mathrm{~mL} \mathrm{O}_{2} \mathrm{~g}^{-1} \mathrm{~h}^{-1}$ (Bartholomew et al. 1964), compared with $0.74 \mathrm{~mL} \mathrm{O}_{2} \mathrm{~g}^{-1} \mathrm{~h}^{-1}$ for $P$. breviceps (mass $=132 \mathrm{~g}$; Fleming 1980) and $1.14 \mathrm{~mL} \mathrm{O}_{2}$ $\mathrm{g}^{-1} \mathrm{~h}^{-1}$ for C. nanus (mass $=21 \mathrm{~g}$; Geiser 1993). Urea recycling by the two marsupials may also have assisted in lowering their nitrogen requirements. Although the ability of $C$. nanus and $P$. breviceps to recycle urea has not been measured, at least two related species are able to do so (Petauroides volans and Trichosurus vulpecula; Foley and Hume 1987).

Differences in the digestibility of pollen nitrogen may have increased the differences between the maintenance nitrogen requirements of $S$. australis and the other species. The feces of

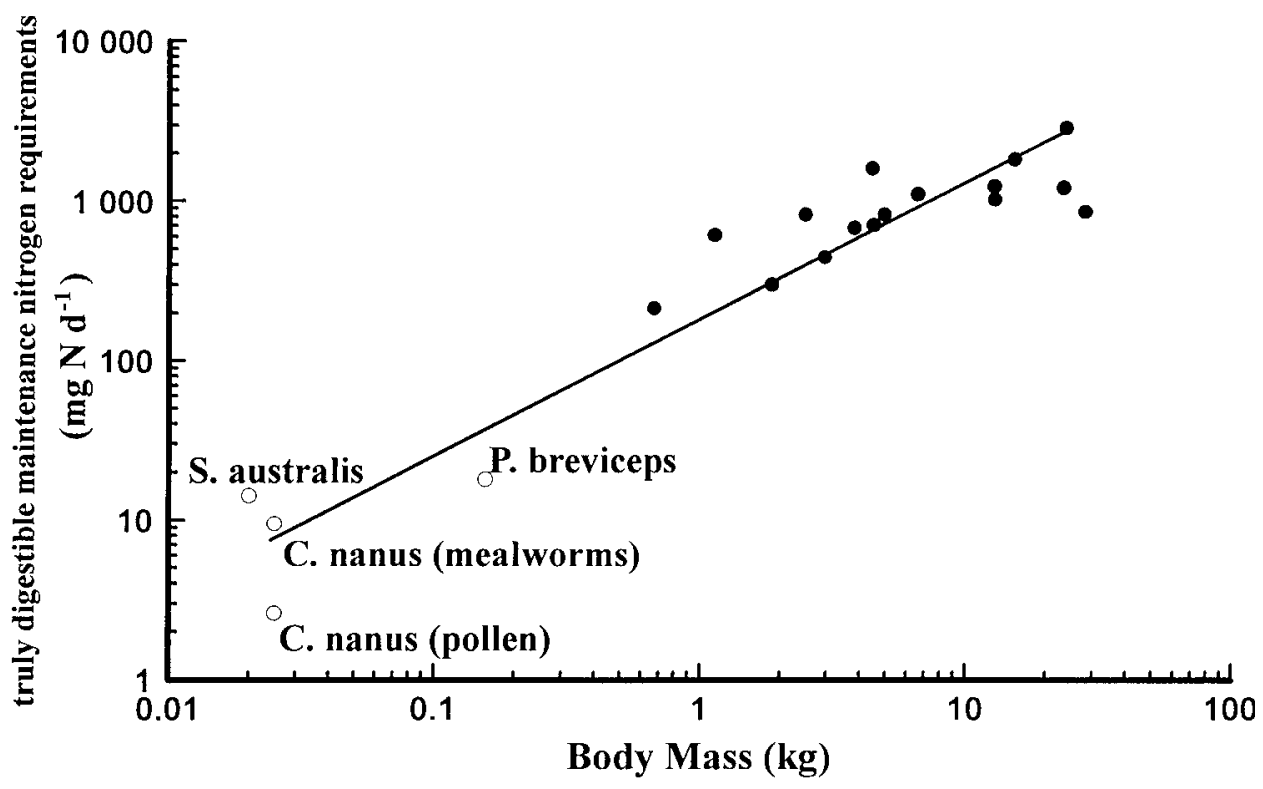

Figure 3. The relationship between the truly digestible maintenance nitrogen requirements $(t d M N R)$ range of diprotodont marsupials and their body mass $(M) . t d M N R=179 M^{0.855}$. Open circles, mammals fed Eucalyptus pollen and Cercartetus nanus fed mealworms; filled circles, other marsupials. The value for the Queensland blossom bat, Syconycteris australis, was not used in determining the regression. The truly digestible maintenance nitrogen requirements of mammals other than C. nanus were converted from units of $\mathrm{mg} \mathrm{N} \mathrm{kg} \mathrm{N}^{-0.75} \mathrm{~d}^{-1}$ as reported values in mg $\mathrm{N} \mathrm{d}^{-1}$ were not available. The body masses and nitrogen requirements of the various marsupials are listed in the appendix. 
free-living $C$. nanus and $P$. breviceps contained similar proportions of empty Banksia pollen grains (65\% and 66\%; van Tets and Whelan 1997). However, the mean proportion of empty grains (53\%-55\%; Law 1992b; Woodside and Pyke 1995) in the feces of $S$. australis is significantly lower $(P<0.05, t$-test; Zar 1996), possibly as a result of its fast gut-passage rate (Law $1992 b$ ). The digestibility of pollen nitrogen is likely, then, to be lower for S. australis than it is for the other two species. It is possible that $S$. australis is using a digestive strategy similar to the pollen-feeding lorikeets. These birds have simple digestive tracts and fast gut-passage rates, relying on the constant passage of partially digested pollen through their digestive tracts to meet their nitrogen needs, rather than on the complete digestion of pollen (Richardson and Wooller 1990).

\section{Summary}

Cercartetus nanus is capable of maintaining its nitrogen requirements on an exceptionally low level of pollen nitrogen. Eucalyptus pollen was a very high-quality protein source for this species and its biological value was higher than that of some high-quality animal protein sources, such as beef muscle, to $R$. norvegicus. Similar results have also been obtained for $P$. breviceps on a similar pollen diet (Smith and Green 1987). The similarity of the amino acid composition of the pollen mixture to that of $B$. ericifolia pollen suggests that the biological value of Banksia pollen to C. nanus would also be high. When these animals ingest large quantities of pollen in the field, they should obtain a substantial amount of nitrogen. Provided it is present in sufficient density, free-living $C$. nanus should be able to use pollen protein to meet their nitrogen requirements.

\section{Acknowledgments}

We thank Professor R. Whelan and Dr. K. Withers for their advice during this project. I.v.T. was supported during the research by an Australian Postgraduate Research Award, and the research was assisted financially by the Pieus Legaat of J. H. van den Ende and S. A. Noodt and by a Joyce W. Vickery grant from the Linnaean Society of New South Wales. We thank C. J. van Tets and S. A. Szarka for their assistance with the feeding trials and N. Dunningham, who made the metabolism cages.

\section{Appendix}

Table A1: Truly digestible maintenance nitrogen requirements of diprotodont marsupials

\begin{tabular}{|c|c|c|c|c|}
\hline Species & Protein Source & Mass (kg) & $\begin{array}{l}\text { Maintenance } \\
\text { Nitrogen } \\
\text { Requirement } \\
\left(\mathrm{mg} \mathrm{N} \mathrm{d}^{-1}\right)\end{array}$ & Reference \\
\hline Cercartetus nanus ............. & Eucalyptus pollen & .025 & 2.6 & This study \\
\hline C. nanus ........................ & Mealworms & .025 & 9.5 & This study \\
\hline Petaurus breviceps ............. & Eucalyptus pollen & .156 & 18 & Smith and Green 1987 \\
\hline Pseudocheirus peregrinus ...... & Eucalyptus foliage & .67 & 215 & Chilcott and Hume 1984 \\
\hline Petauroides volans .............. & Eucalyptus foliage & 1.13 & 614 & Foley and Hume 1987 \\
\hline Trichosurus vulpecula .......... & Eucalyptus foliage & 2.5 & 830 & Foley and Hume 1987 \\
\hline T. vulpecula .................. & Casein & 1.9 & 301 & Wellard and Hume 1981 \\
\hline Vombatus ursinus ............. & Maize and casein & 27.9 & 861 & Barboza et al. 1993 \\
\hline Lasiorhinus latifrons ........... & Maize and casein & 23.1 & 1,222 & Barboza et al. 1993 \\
\hline Phascolarctos cinereus ......... & Eucalyptus foliage & 6.6 & 1,113 & Cork 1986 \\
\hline Aepyprymnus rufescens ........ & Varied & 2.9 & 447 & Wallis and Hume 1992 \\
\hline Thylogale thetis ............... & Lucerne & 4.4 & 1,616 & Hume 1977 \\
\hline Macropus eugenii .............. & Lucerne & 4.9 & 711 & Hume 1977 \\
\hline M. eugenii ..................... & Oat chaff & 4.9 & 821 & Barker 1968 \\
\hline Macropus parma ............. & Lucerne & 3.8 & 680 & Hume 1986 \\
\hline Macropus robustus ............ & Oat chaff & 15.1 & 1,029 & Brown and Main 1967 \\
\hline M. robustus .................. & Oat chaff and casein & 12.8 & 1,841 & Foley et al. 1980 \\
\hline Macropus giganteus ........... & Oat chaff and casein & 23.6 & 2,888 & Foley et al. 1980 \\
\hline
\end{tabular}




\section{Literature Cited}

Arnould J. 1986. Aspects of the Diet of the Eastern Pygmy Possum, Cercartetus nanus. BSc honours thesis. Monash University, Melbourne.

Barboza P.S., I.D. Hume, and J.V. Nolan. 1993. Nitrogen metabolism and requirements of nitrogen and energy in the wombats (Marsupialia: Vombatidae). Physiol Zool 66: 807-828.

Barker S. 1968. Nitrogen balance and water intake in the Kangaroo Island wallaby, Ptotemnodon eugenii (Desmarest). Aust J Exp Biol Med Sci 46:17-32.

Bartholomew G.A., P. Leitner, and J.E. Nelson. 1964. Body temperature, oxygen consumption and heart rate in three Australian flying foxes. Physiol Zool 37:179-198.

Bosshardt D.K. and R.H. Barnes. 1946. The determination of metabolic fecal nitrogen and protein digestibility. J Nutr 31: 13-21.

Brice A.T. and C.R. Grau. 1991. Protein requirements of Costa's hummingbirds Calypte costae. Physiol Zool 64:611-626.

Brody S. 1974. Bioenergetics and Growth. Hafner, New York.

Brown G.D. and A.R. Main. 1967. Studies on marsupial nutrition. V. The nitrogen requirements of the euro, Macropus robustus. Aust J Zool 15:7-27.

Chilcott M.J. and I.D. Hume. 1984. Nitrogen and urea metabolism and nitrogen requirements of the common ringtail possum, Pseudocheirus peregrinus, fed Eucalyptus andrewsii foliage. Aust J Zool 32:615-622.

Cork S.J. 1986. Foliage of Eucalyptus punctata and the maintenance nitrogen requirements of Koalas, Phascolarctos cinereus. Aust J Zool 34:17-23.

Dadd R.H. 1977. Qualitative requirements and utilization of nutrients: insects. Pp. 305-346 in M. Rechcigl, ed. Nutritional Requirements. Vol. 1. CRC Handbook Series in $\mathrm{Nu}-$ trition and Food. CRC Press, Cleveland.

Foley W.J. and I.D. Hume. 1987. Nitrogen requirements and urea metabolism in two arboreal marsupials, the greater glider (Petauroides volans) and the brushtail possum (Trichosurus vulpecula), fed Eucalyptus foliage. Physiol Zool 60: 241-250.

Foley W.J., I.D. Hume, and R. Taylor. 1980. Protein intake and requirements of the eastern wallaroo and the eastern grey kangaroo. Bull Aust Mammal Soc 6:34-35.

Food and Agriculture Organisation. 1970-1972. Amino-Acid Content of Foods and Biological Data on Proteins. Food Policy and Science Service, Nutrition Division, Food and Agriculture Organisation, Rome.

Ferrari S.F. and K.B. Strier. 1992. Exploitation of Mabea fistulifera nectar by marmosets (Callithrix flaviceps) and muriquis (Brachyteles arachnoides) in south-east Brazil. J Trop Ecol 8:225-239.

Fleming M.R. 1980. Thermoregulation and torpor in the sugar glider, Petaurus breviceps (Marsupialia: Petauridae). Aust J Zool 28:521-534.

Fleming T.H. and V.J. Sosa. 1994. Effects of nectarivorous and frugivorous mammals on reproductive success of plants. J Mammal 75:845-851.

Frye F.L. 1993. A Practical Guide for Feeding Captive Reptiles. Krieger, Malabar.

Geiser F. 1993. Hibernation in the eastern pygmy possum, Cercartetus nanus (Marsupialia: Burramyidae). Aust J Zool 41: 67-75.

Goldingay R.L., S.M. Carthew, and R.J. Whelan. 1987. Transfer of Banksia spinulosa pollen by mammals: implications for pollination. Aust J Zool 35:319-325.

. 1991. The importance of non-flying mammals in pollination. Oikos 61:79-87.

Huang C., S. Ward, and A.K. Lee. 1987. Comparison of the diets of the feathertail glider, Acrobates pygmaeus, and the eastern pygmy possum, Cercartetus nanus, (Marsupialia: Burramyidae) in sympatry. Aust Mammal 10:47-50.

Hume I.D. 1977. Maintenance nitrogen requirements of the macropod marsupials Thylogale thetis, red-necked pademelon, and Macropus eugenii, tammar wallaby. Aust J Zool 25: 407-417.

- 1982. Digestive Physiology and Nutrition of Marsupials. Cambridge University Press, Cambridge.

- 1986. Nitrogen metabolism in the parma wallaby, Macropus parma. Aust J Zool 34:147-155.

Law B.S. 1992a. The maintenance nitrogen requirements of the Queensland blossom bat (Syconycteris australis) on a sugar/ pollen diet: is nitrogen a limiting resource? Physiol Zool 65: 634-648.

— 1992b. Physiological factors affecting pollen use by Queensland blossom bats, Syconycteris australis. Funct. Ecol. 6:257-264.

Martínez del Rio C. 1994. Nutritional ecology of fruit-eating and flower-visiting birds and bats. Pp. 103-127 in D.J. Chivers and P. Langers, eds. The Digestive System in Mammals: Food, Form and Function. Cambridge University Press, Cambridge.

McDonald P., R.A. Edwards, and J.F.D. Greenhalgh. 1973. Animal Nutrition. 2d ed. Longman, London.

Mitchell H.H. and J.R. Beadles. 1950. Biological value of six partially purified proteins for the adult albino rat. J Nutr 40: 925-940.

Moir R.J. 1994. The "carnivorous" herbivores. Pp. 87-102 in D.J. Chivers and P. Langers, eds. The Digestive System in Mammals: Food, Form and Function. Cambridge University Press, Cambridge.

Nagy K.A. and M.H. Knight. 1994. Energy, water and food use by springbok antelope (Antidorchas marsupialis) in the Kalahari desert. J Mammal 75:860-872.

Raven P.H., R.F. Evert, and S.E. Eichhorn. 1986. Biology of Plants. 4th ed. Worth, New York. 
Rebelo A.G. and G.J. Breytenbach. 1987. Mammal pollination in the Cape flora. Pp. 109-125 in A.G. Rebelo, ed. A Preliminary Synthesis of Pollination Biology in the Cape Flora. South African National Scientific Programmes Report 141. Council for Scientific and Industrial Research, Pretoria.

Richards C.G.J., A.C. White, E. Hurrell, and F.E.F. Price. 1984. The food of the common dormouse, Muscardinus avellanarius, in south Devon. Mammal Rev 14:19-28.

Richardson K.C. and R.D. Wooller. 1990. Adaptations of the alimentary tracts of some Australian lorikeets to a diet of pollen and nectar. Aust J Zool 38:581-586.

Richardson K.C., R.D. Wooller, and B.G. Collins. 1986. Adaptations to a diet of nectar and pollen in the marsupial Tarsipes rostratus. J Zool (Lond) 208:285-297.

Robbins C.T. 1993. Wildlife Feeding and Nutrition. 2d ed. Academic Press, New York.

Sauer J.J.C. 1983. Food selection by giraffes in relation to changes in the chemical composition of the leaves. S Afr J Anim Sci 13:40-42.

Smith A.P. 1982. Diet and feeding strategies in the marsupial sugar glider in temperate Australia. J Anim Ecol 51:149-166.

Smith A.P. and S.W. Green. 1987. Nitrogen requirements of the sugar glider (Petaurus breviceps), an omnivorous marsupial, on a honey-pollen diet. Physiol Zool 60:82-92.
Stace P. 1987. Pollen quality_-heath leaved banksia, red cobbed banksia, Banksia ericifolia. Australas Beekeeper 89:97-98.

Tomlin E., H. McLean, and S. Caveney. 1993. Active accumulation of glutamate and aspartate by insect epidermal cells. Insect Biochem Mol Biol 23:561-569.

Turner V. 1984a. Banksia pollen as a protein source in the diet of two Australian marsupials: Cercartetus nanus and Tarsipes rostratus. Oikos 43:53-61.

- 1984b. Eucalyptus pollen in the diet of the feathertail glider, Acrobates pygmaeus. Aust Wild Res 11:77-81.

van Tets I.G. 1997. Extraction of nutrients from Protea pollen by African rodents. Belg J Zool 127(suppl. 1):59-65.

van Tets I.G. and R.J. Whelan. 1997. Banksia pollen in the diet of Australian mammals. Ecography 20:499-505.

Wallis I.R. and I.D. Hume. 1992. The maintenance nitrogen requirements of potoroine marsupials. Physiol Zool 65: 1246-1270.

Wellard G.A. and I.D. Hume. 1981. Digestion and digesta passage in the brushtail possum, Trichosurus vulpecula (Kerr). Aust J Zool 29:147-156.

Woodside D.P. and G.H. Pyke. 1995. A comparison of bats and birds as pollinators of Banksia integrifolia in northern New South Wales, Australia. Aust Mammal 18:9-18.

Zar J.H. 1996. Biostatistics. Prentice Hall, Upper Saddle River, N.J. 